\title{
Mite Sarcoptes scabiei Varieties Hominis in South Sumatra: Specific Identification and Comparative Study
}

\author{
Yessi Arisandi ${ }^{1,2}$, Chairil Anwar ${ }^{3 *}$, Salni Salni ${ }^{4}$, Dadang Hikmah Purnama ${ }^{5}$, Novrikasari Novrikasari ${ }^{6}$, Ahmad Ghiffari $^{7}$ \\ ${ }^{1}$ Doctoral Programme, Department of Environmental Science, Universitas Sriwijaya, Palembang, Indonesia; ${ }^{2}$ Department of Nursing \\ Science, Siti Khadijah Institute of Health Sciences, Palembang Indonesia; ${ }^{3}$ Department of Parasitology, Faculty of Medicine, \\ Universitas Sriwijaya, Palembang, Indonesia; ${ }^{4}$ Department of Biology, Faculty of Mathematics and Natural Science, Universitas \\ Sriwijaya, Palembang, Indonesia; ${ }^{5}$ Department of Sociology, Faculty of Social and Political Science, Universitas Sriwijaya, Palembang, \\ Indonesia; ${ }^{6}$ Department of Occupational Safety and Health, Faculty of Public Health, Universitas Sriwijaya, Palembang, Indonesia; \\ ${ }^{7}$ Department of Parasitology, Faculty of Medicine, Universitas Muhammadiyah Palembang, Palembang, Indonesia
}

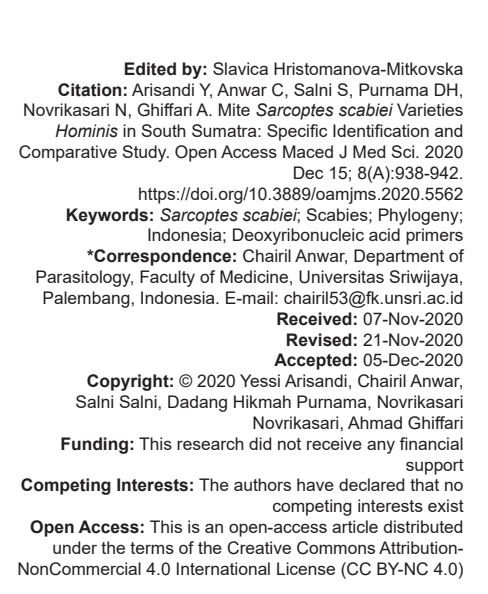

Abstract

BACKGROUND: Sarcoptes scabiei mites have more than 15 genetically diverse varieties from various hosts. Identification of $\mathrm{S}$. scabiei mite varieties hominis as an intervention in its prevention is still rarely done.

AIM: This study aimed to observe the genetic relationship of the mite S. scabiei varieties hominis compare to the parasite S. scabiei varieties hominis in other regions.

METHODS: This research used polymerase chain reaction (PCR) and sequencing methods with 165 gene-specific primers. From $32 \mathrm{~S}$. scabiei samples, 22 samples were identified as varieties hominis that was marked by the appearance of the band at $132 \mathrm{bp}$

RESULTS: S. scabiei mites hominis varieties from South Sumatra (Yessi Scabies A2 and Yessi Scabies B3) have similarities with deoxyribonucleic acid (DNA) strands with S. scabiei hominis varieties from China (KJ781377 and KJ781376). In contrast, Yessi Scabies A1 has similarities with DNA strands with mite S. scabiei varieties hominis from Australia (AY493402). Still, all the DNA strands, this research is different from S. scabiei mites DNA strands hominis from Panama and Pakistan.

CONCLUSION: The PCR method is advantageous and specific in identifying mites S. scabiei hominis varieties, the cause of scabies in humans.

\section{Introduction}

Scabies is a contagious skin disease caused by mites Sarcoptes scabiei originating from human and animal hosts [1]. According to the World Health Organization, scabies is one of the most significant diseases in the world from six epidermal skin diseases with 300 million cases annually [1]. Scabies includes endemic skin diseases in tropical and subtropical regions, such as in Africa, Egypt, Central America, South America, Northern Australia, central Australia, the Caribbean Islands, India, and Southeast Asia [2]. Scabies caused by mites $S$. scabiei can enter the human skin layer (stratum corneum) in $<30 \mathrm{~min}$. The several reactions of insects in the skin are allergic reactions, inflammation, and the response of body immune in maintaining healthy skin [3].

Skin sensitivity to mite $S$. scabiei body and excretion results, mite $S$. scabiei secretion in the skin layer (stratum corneum) causes itching, resulting in scratching activity on the skin. The results of scratching cause lesions on the surface [2]. The injury is the opening of the stratum corneum layer, which causes the bacteria Streptococcus pyogenes and Staphylococcus aureus enter, resulting in secondary infections [4]. Secondary infections cause impetigo, cellulitis, and abscesses and can cause life-threatening diseases, including sepsis, and glomerulonephritis [5]. Scabies examination through clinical symptoms was sometimes less accurate caused by similarities with other skin diseases. Scabies in humans is still ignored by the community, especially in students living in Islamic boarding schools because of a lack of knowledge about the causes, transmission, prevention, and complications of scabies.

There are various methods in diagnosing scabies, namely, skin scrapings, dermatoscopy, burrow ink, and tetracycline fluorescence. Grover and Jakhar (2017) use skin scrapings and dermatoscopy methods to identify scabies [6]. Examination of skin scrapings is done by putting the results of skin scrapings under 
a microscope. On the other hand, an investigation by dermatoscopy is more practical and accurate because of mites. S. scabiei can be seen in the epidermis layer of the skin but cannot identify the mite varieties. Amanda et al. (2018) identified scabies by examining the burrow ink test by skin scrapping [7].

The polymerase chain reaction (PCR) method can detect genotype differences between $S$. scabiei mites from different hosts, including pigs, rabbits, foxes, hedgehogs, and humans [3]. Host populations that are adapted and located separately from S. scabiei are characterized using $16 \mathrm{~S}$ primers [8]. Mites S. scabiei has more than 15 genetically diverse varieties from various hosts [9].

Research on the insects that cause scabies in human is still rarely done in Indonesia. Identification of parasites S. scabiei varieties hominis using PCR method with $16 S$ primers has never been done in the South Sumatra region, especially in Islamic boarding schools. This study aims to identify the causes of scabies that occur in humans and genetically compare the mite S. scabiei hominis varieties in South Sumatra with other regions.

\section{Methods}

\section{Study area}

The research was conducted in boarding school in Palembang city (address: Depaten lama road 27 Ilir; 104 45'18"east longitude, 2059'37" south latitude) and Indralaya district (address: Sakatiga village; $104^{0} 45^{\prime} 18$ "east longitude, $3^{0} 15^{\prime} 22^{\prime \prime}$ south latitude), South Sumatera, Indonesia. The analysis was carried out from August to December 2018.

\section{Collecting samples}

This research is an experimental analytic with a cross-sectional design. The sample came from the skin scrapings of respondents with scabies who lived in two Islamic boarding schools (RU boarding school and MS boarding school) located in South Sumatra. The sample examination was carried out in the laboratory of the Faculty of Medicine, Universitas Sriwijaya, Palembang, Indonesia. Respondents who suffer from scabies do skin scraping by lifting the papules or the roof of the tunnel that is skinned using a sterile scalpel number 15. A complete papule/tunnel is dropped with mineral oil or $10 \% \mathrm{KOH}$. Scrapings are placed on the slide and then given mineral oil or immersion oil and then given a cover glass and examined under a microscope with a magnification of 10-40× [10]. Examination with scrapings in diagnosing scabies is known to be $100 \%$ specificity and $90-95 \%$ sensitivity when scraping is done at the right location. This study has received ethical approval at the Faculty of Public Health, Universitas Sriwijaya No. 289/UN9.1.10/KKE/2018.

\section{Deoxyribonucleic acid (DNA) extraction}

Human skin samples were placed in a tube. Ethanol added, then put into a $1.5 \mathrm{ml}$ microcentrifuge tube and added with a $180 \mu \mathrm{l}$ ATL buffer, $20 \mu \mathrm{l}$ proteinase $\mathrm{K}$, mixed with vortex and incubated at $56^{\circ} \mathrm{C}$ for $24 \mathrm{~h}$ until lysis, occasional vortex during incubation, vortex 15. Samples were then added $200 \mu \mathrm{AL}$ buffer, vortex, and incubated at $56^{\circ} \mathrm{C} 10^{\prime}$. The next sample is added with $100 \%$ ethanol and mixed with a vortex. The mixture is then taken with a dropper pipette and put in a Dnase Mini spin column $2 \mathrm{ml}$ collection tube, $6000 \times$ $\mathrm{g}$ (8000 rpm) centrifuge for 1', and then the collection tube is discarded. A $2 \mathrm{ml}$ spin column tube was added with $500 \mu \mathrm{l}$ Buffer AW1 and centrifuged 1'6000 × $\mathrm{g}$ (8000 rpm), and then the collection tube was removed. A $2 \mathrm{ml}$ spin column tube was added with $500 \mu \mathrm{l}$ AW2 buffer and centrifuged for 4' at 13,000 rpm, and then the collection tube was removed. The $2 \mathrm{ml}$ spin column tube is centrifuged 1'at 13,000 rpm. Then, the collection tube is removed. $1.5-2 \mathrm{ml}$ of the spin-column machine is transferred into the microcentrifuge tube. DNA elution is carried out by adding $200 \mu \mathrm{l}$ of $\mathrm{AE}$ buffer in the middle of the spin column membrane tube. Incubation is performed at $1^{\prime}$ room temperature $\left(15-25^{\circ} \mathrm{C}\right)$, while centrifugation is at 1' $6000 \times \mathrm{g}(8000 \mathrm{rpm})$. The process is repeated in eight steps to increase the amount of DNA.

\section{PCR and sequencing}

The PCR application lasts for 40 cycles. DNA amplification results were detected by electrophoresis for 45 min with 85 volts using $2 \%$ agarose $(1 \mathrm{~g}$ agarose in $50 \mathrm{ml} \mathrm{TAE}$ and added $2.5 \mu \mathrm{l}$ ETBR). The amplicons from samples and markers are electrophoretic, and the electrophoretic DNA can be seen under ultraviolet light on the Biorad doc gel. First pair of PCR reaction, that is, Forward: 5' - GGG TCT TTT TGT CTT GGAATAAA - 3'. Reverse: 5' - CTA AGG TAG CGA AAT CAT TAG C- 3' using $16 \mathrm{~S}$ primers [11]. Sequencing products were analyzed using $\mathrm{ABI} 3730 \mathrm{xl}$ Genetic Analyzer (Applied Biosystems, Foster City, CA, USA). The sequences that have been collected are stored in the NCBI GenBank database.

\section{Phylogenetic tree construction}

Phylogenetic tree analysis was built using Mega 6.0 software according to Tamura et al. and Harnelly et al. [12], [13]. The phylogenetic tree was used to search for the comparison of mite S. scabiei varieties hominis from various regions taken from $\mathrm{NCBI}$ GenBank data. 


\section{Results}

From the results of PCR analysis using primers used $16 \mathrm{~S} F / \mathrm{R}$ on $2 \%$ agarose gel, there is a specific band of $132 \mathrm{bp}$ which identified the presence of mite $S$. scabiei varieties hominis in human samples.

From 12 DNA specimens derived from scrapings of human skin suffering from scabies, the samples RU1, RU3B, RU4A, RU7A, RU7B, RU8, and RU10A showed that $S$. scabiei mite DNA was positive which was indicated by the appearance of bands on the target band at 132bp (Figure 1a). The samples of RU2A, RU2B, RU3A, RU5, and RU6 show that the DNA of the mite. S. scabiei is negative, which is indicated by the absence of bands on the target band at 132 bp. From 13 DNA specimens derived from scrapings of human skin suffering from scabies, in samples with codes RU.10B, RU.11, MS.2, MS.3, MS.4, MS.5A, MS.5B, MS.6, MS.7, MS.8A, and MS.8B showed that the mite $S$. scabiei varieties hominis was positive which was indicated by the appearance of bands on the target band at $132 \mathrm{bp}$ (Figure 1b). The RU12 and MS.1 code samples show that the mite $S$. scabiei varieties hominis of DNA is negative, which is indicated by the absence of bands on the target band at $132 \mathrm{bp}$. From 7 DNA specimens derived from scrapings of human skin suffering from scabies, in code samples of MS.10, MS.11, MS.12, and MS.13A showed that mite S. scabiei varieties hominis DNA was positive which was marked by the appearance of bands on the target band, that is, at $132 \mathrm{bp}$ (Figure 1c). The MS9A, MS9B, and MS13B code samples show that the mite $S$. scabiei DNA of hominis varieties is negative, which is characterized by the absence of bands on the target band at $132 \mathrm{bp}$.

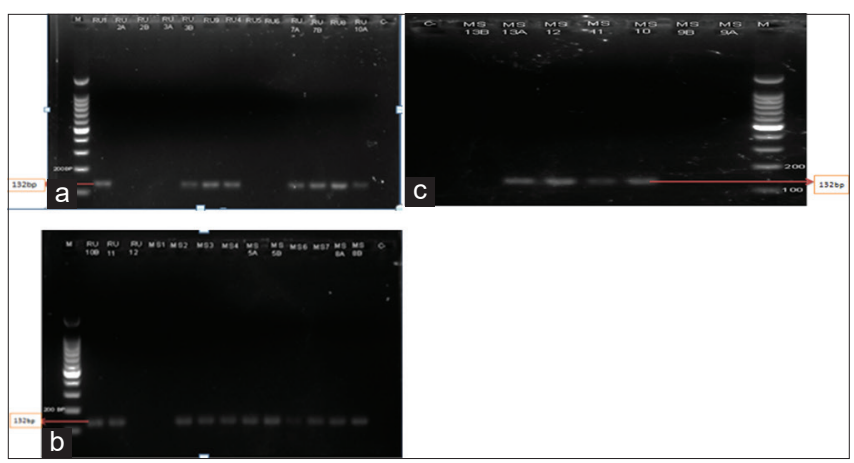

Figure 1: (a-c) Positive band of Sarcoptes scabiei

\section{Phylogenetic tree}

Sequencing analysis of $16 S$ S. scabiei primer varieties hominis originating from different hosts from Panama 3 sequence types, from Australia 7 sequence types, from Pakistan 1 sequence type, and from China 2 sequence types form a cluster on a phylogenetic tree together with reference sequences from GenBank are the broad host and geographic distribution of $S$. scabiei mites hominis varieties (Figure 2). Mite $S$. scabiei varieties hominis from South Sumatra (Yessi Scabies A2) and (Yessi Scabies B3) is genetically related to parasite S. scabiei varieties hominis China (KJ781377 and KJ781376). Furthermore, mites S. scabiei from South Sumatra (Yessi Scabies A1) is genetically related to insect S. scabiei varieties hominis from Australia (AY493402).

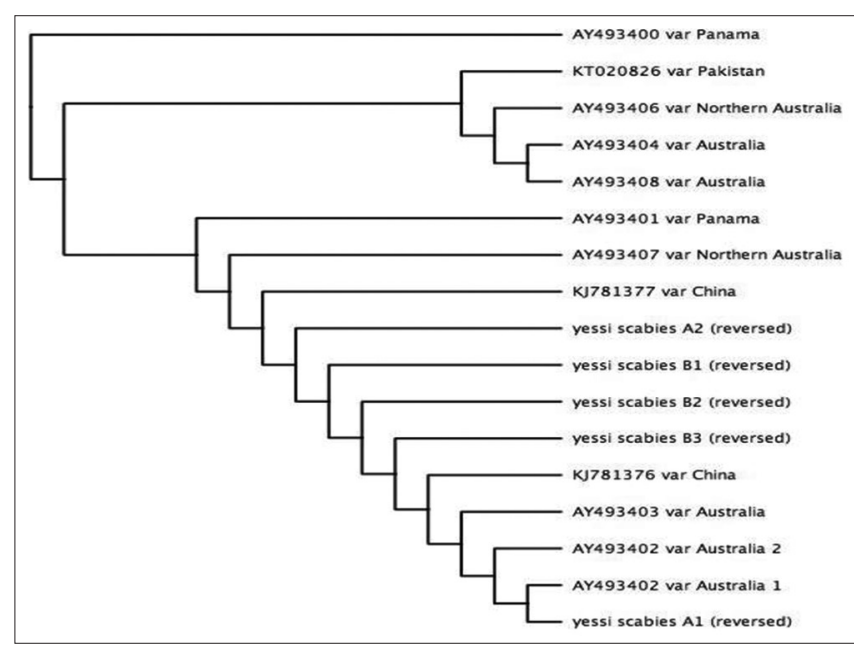

Figure 2: Identification of mite Sarcoptes scabiei hominis varieties with $16 \mathrm{~S}$ gene primers based on nucleotide sequences

\section{Discussion}

Based on PCR test results with a sample of 32 mites S. scabiei, the parasite S. scabiei DNA was positive with a $132 \mathrm{bp}$ band of 22 insects $S$. scabiei varieties hominis. This study is in line with the results of Naz et al., 2018, that samples from hospital patients in Pakistan are positive if there are mite $S$. scabiei varieties hominis DNA marked by the presence of band bands at a target of $600 \mathrm{bp}$ using $16 \mathrm{~S}$ primers and harmful if no band was found from the mite $S$. scabiei varieties hominis [11]. This study was also supported by research by Walton and Currie, Naz et al., Walton et al. and Walton et al. [2], [11], [14], [15], the length of band fragments on DNA mite S. scabiei varieties hominis with the band between $138 \mathrm{bp}$ and $178 \mathrm{bp}$. Insects have a minimum body size. Female ticks are with a capacity of $0.3 \mathrm{~mm}$ and width of $0.25 \mathrm{~mm}$, and male bugs are with a size of half of the size of female insects [16]. Mite size was $<0.4 \mathrm{~mm}$ [11]. Mites S. scabiei hominis varieties hominis can be able to survive in the environment outside the human body, for 24-36 $\mathrm{h}$ with normal room conditions that have a temperature of $21^{\circ} \mathrm{C}$. Mites S. scabiei varieties hominis are associated with the environment with residential density [17]. High risk of transmission of scabies to dense residential settings such as Thai orphanages (87\%) [5], [18], refugee camps in Sierra Leone (67\%) [5], and Islamic religious schools in Bangladesh (61\%) [19]. Research conducted by Walton et al. [15] randomized phylogenetic grouping of several S. scabiei mites originating from dogs and human hosts. 
The results obtained are that there are different forms of groups that prove that in endemic areas, scabies transmission occurs through from human to human.

Sequencing analysis with $16 \mathrm{~S}$ primers from mites S. scabieivarieties hominis that come from different hosts from Panama (three sequence types), Australia (seven sequence types), Pakistan (one sequence type), and China (two sequence types) formed a cluster in phylogenetic trees with reference sequences from a gene bank. This reflects the broad host and distribution of the location of the S. scabiei population variety of hominis. Mites S. scabiei varieties hominis from Southern Sumatra (Yessi Scabies A2 and Yessi Scabies B3) genetically has similarities with $S$. scabiei mites varieties hominis originating from China (KJ781377 and KJ781376). Yessi Scabies A1 is genetically similar to $S$. scabiei hominis variety from Australia (AY493402). Mite S. scabiei varieties hominis originating from Pakistan (KT020826) do not have the genetic similarity of all mite S. scabiei varieties hominis in Southern Sumatra. Based on the history of the origin of scabies, the first incident of Scabies in Australia occurred in 1854 due to the presence of Chinese people who brought scabies to come to Victoria. Based on medical records the first Scabies incident occurred in Northern Australia, which was located more than 3000 km from Victoria in 1944 by Lt Col, the first shipment of Chinese people in the golden age of Victoria in 1954 [19].

\section{Conclusion}

The PCR method is advantageous and specific in identifying mites $S$. scabiei hominis varieties, the cause of scabies in humans. Epidemiological studies of parasites $S$. scabiei are needed in the prevention and control of scabies in humans in residential areas, especially in Islamic boarding schools.

\section{Acknowledgement}

The authors would express their sincere gratitude to DIPA of Public Service Agency of Universitas Sriwijaya 2020 for administrative and technical support on this research (SP DIPA-023.17.2.677515/2020).

\section{References}

1. Morgan MS, Rider SD, Arlian LG. Identification of antigenic Sarcoptes scabiei proteins for use in a diagnostic test and of non-antigenic proteins that may be immunomodulatory. PLoS Negl Trop Dis. 2017;11(6):e0005669. https://doi.org/10.1371/ journal.pntd.0005669

PMid:28604804

2. Walton SF, Currie BJ. Problems in diagnosing scabies, a global disease in human and animal populations. Clin Microbiol Rev. 2007;20(2):268-79. https://doi.org/10.1128/cmr.00042-06 PMid: 17428886

3. Erster O, Roth A, Pozzi S, Bouznach A, Shkap V. First detection of Sarcoptes scabiei from the domesticated pig (Sus scrofa) and genetic characterization of $S$. scabiei from pet, farm and wild hosts in Israel. Exp Appl Acarol. 2015;66(4):605-12. https://doi. org/10.1007/s10493-015-9926-z

PMid:26002310

4. Engelman D, Kiang K, Chosidow O, McCarthy J, Fuller C Lammie $\mathrm{P}$, et al. Toward the global control of human Scabies: Introducing the international alliance for the control of scabies. PLoS Negl Trop Dis. 2013;7(8):5-8. https://doi.org/10.1371/ journal.pntd.0002167

PMid:23951369

5. Hay RJ, Steer AC, Chosidow O, Currie BJ. Scabies: A suitable case for a global control initiative. Curr Opin Infect Dis. 2013;26(2):107-9. https://doi.org/10.1097/ qco.0b013e32835e085b

PMid:23302759

6. Grover C, Jakhar D. Dermoscopy in the diagnosis of scabies. Int J Dermoscopy. 2017;1(2):1-2.

7. Amanda FZ, Hastutiek P, Sabdoningrum EK, Suprihati E, Eliyan $\mathrm{H}$. The conformity of diagnostic test between burrow ink test method with a skin scrapping method of scabies in rabbit (Lepus domesticus). J Pharm Sci. 2018;2(1):29-32. https://doi. org/10.20473/jops.v2i1.16381

8. Amer S, Wahab TA, Metwaly AE, Ye J, Roellig D, Feng Y, et al Preliminary molecular characterizations of Sarcoptes scabiei (Acari: Sarcoptidae) from farm animals in Egypt. PLoS One. 2014;9(4):1-6. https://doi.org/10.1371/journal.pone.0094705

9. Alasaad S, Permunian R, Gakuya F, Mutinda M, Soriguer RC, Rossi L. Sarcoptic-mange detector dogs used to identify infected animals during outbreaks in wildlife. BMC Vet Res. 2012;8:110. https://doi.org/10.1186/1746-6148-8-110

10. Fawcett, RS. Ivermectin use in scabies. Am Fam Physician. 2003;68(6):1089-92.

PMid: 14524395

11. Naz S, Chaudhry FR, Rizvi DA, Ismail M. Genetic characterization of Sarcoptes scabiei var. hominis from scabies patients in Pakistan. Trop Biomed. 2018;35(3):796-803.

12. Tamura K, Stecher K, Peterson D, Filipski A, Kumar S. MEGA6: Molecular evolutionary genetics analysis version 6.0. Mol Biol Evol. 2013;30(12):2725-9. https://doi.org/10.1093/molbev/mst197 PMid:24132122

13. Harnelly E, Thomy Z, Fathiya N. Phylogenetic analysis of Dipterocarpaceae in Ketambe research station, Gunung Leuser National Park (Sumatra, Indonesia) based on RbcL and MatK genes. Biodiversitas. 2018;19(3):1074-80. https://doi. org/10.13057/biodiv/d190340

14. Walton, SF, Dougall A, Pizzutto S, Holt D, Taplin D, Arlian LG, et al Genetic epidemiology of Sarcoptes scabiei (Acari: Sarcoptidae) in Northern Australia. Int J Parasitol. 2004;34(7):839-49. https:// doi.org/10.1016/j.ijpara.2004.04.002

15. Walton, SF, Choy JL, Bonson A, Valle A, McBroom J, Taplin D, et al. Genetically distinct dog-derived and human-derived Sarcoptes scabiei in scabies-endemic communities in Northern Australia. Am J Trop Med Hyg. 1999;4:542-7. https://doi. org/10.4269/ajtmh.1999.61.542

PMid: 10548286 
16. Ugbomoiko, Samuel $U$, Oyedeji SA, Babamale OA, Heukelbach J. Scabies in resource-poor communities in Nasarawa State, Nigeria: Epidemiology, clinical features and factors associated with infestation. Trop Med Int Health. 2018;3(2):59. https://doi.org/10.3390/tropicalmed3020059

PMid:30274455

17. Pruksachatkunakorn C, Wongthanee A, Kasiwat V. Scabies in Thai orphanages. Pediatr Int. 2003;45(6):719-23. https://doi. org/10.1111/j.1442-200x.2003.01811.x

PMid:14651549
18. Terry BC, Kanjah F, Sahr F, Kortequee S, Dukulay I, Gbakima AA Sarcoptes scabiei infestation among children in a displacement camp in Sierra Leone. Public Health. 2001;115(3):208-11. https://doi.org/10.1016/s0033-3506(01)00445-0

PMid:11429717

19. Talukder K, Talukder MQ, Farooque MG, Khairul M, Sharmin F Jerin I, et al. Controlling scabies in madrasahs (Islamic religious schools) in Bangladesh. Public Health. 2013;127(1):83-91. https://doi.org/10.1016/j.puhe.2012.09.004

PMid:23062631 